\title{
Three-Dimensional Network of Cation-Cation-Bound Neptunyl(V) Squares: Synthesis and in Situ Raman Spectroscopy Studies
}

\author{
Geng Bang Jin* \\ Chemical Sciences and Engineering Division, Argonne National Laboratory, Argonne, Illinois \\ 60439, United States
}

Supporting Information 
Figure S1. An absorption spectrum of a $0.120 \mathrm{M} \mathrm{Np}(\mathrm{V})$ (in $\sim 1 \mathrm{M} \mathrm{HCl}$ ) stock solution.

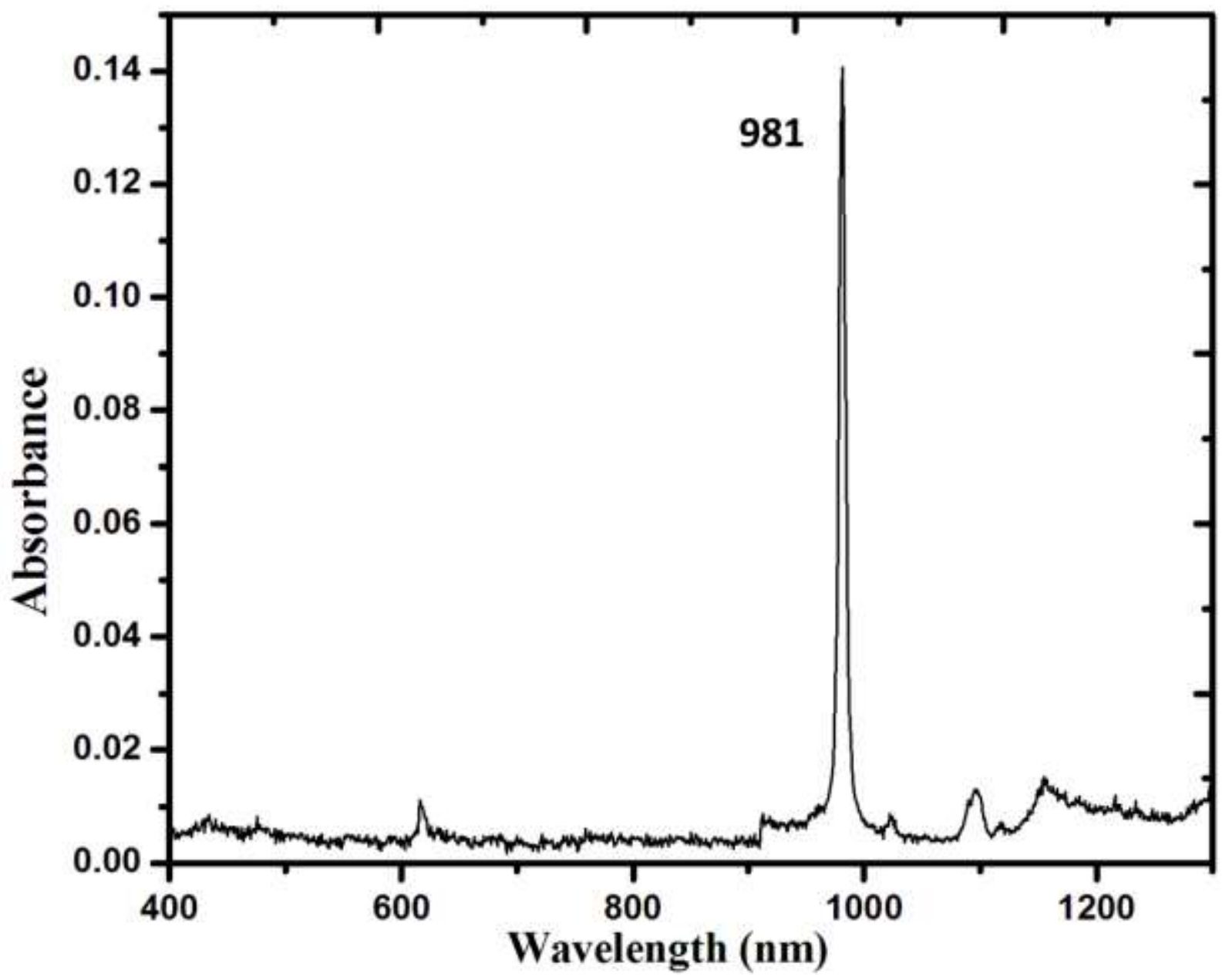


Figure S2: Powder X-ray diffraction pattern of $\left(\mathrm{NpO}_{2}\right) \mathrm{Cl}\left(\mathrm{H}_{2} \mathrm{O}\right)_{2}(\mathbf{1})$ after manually removing the colorless salts.

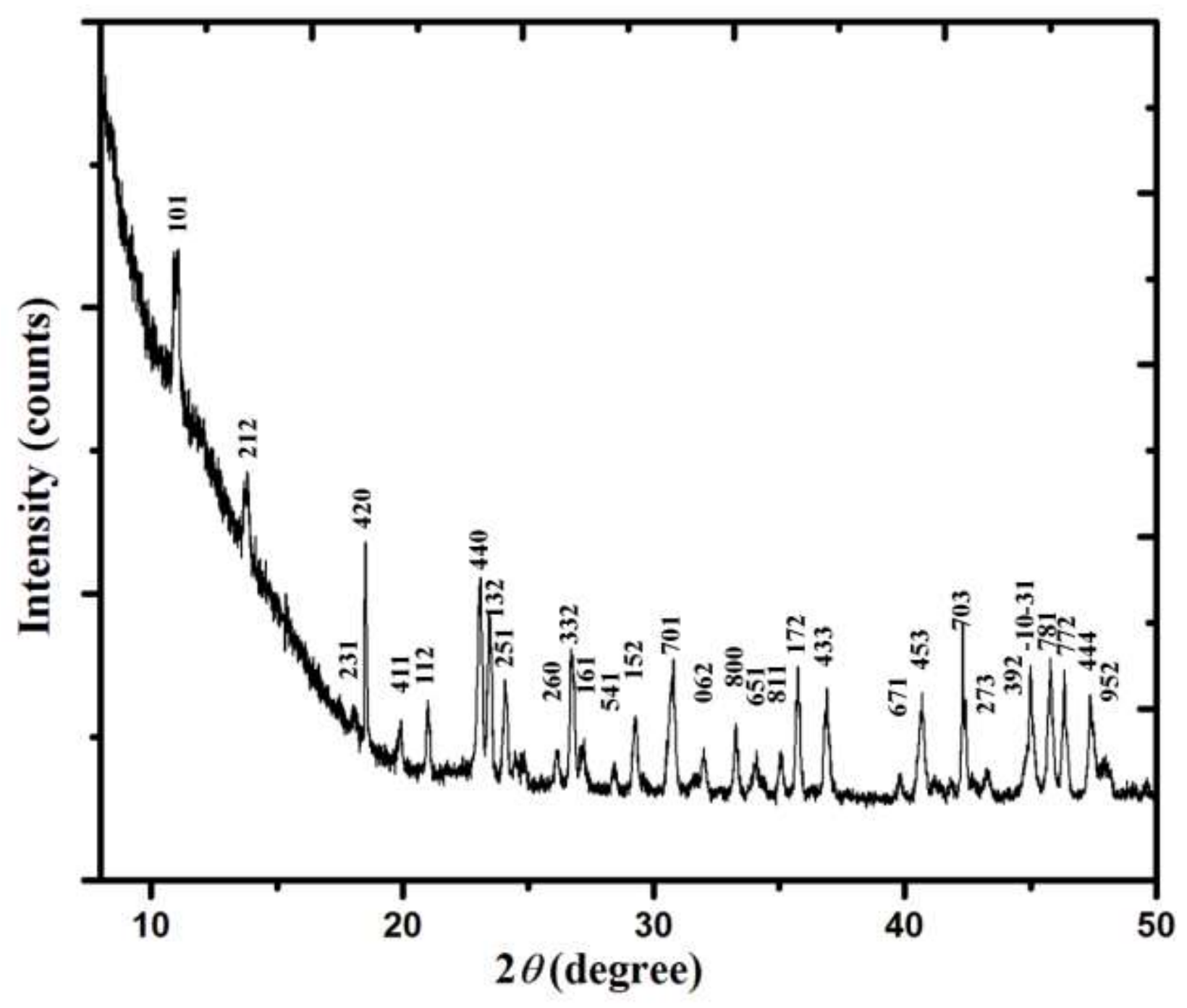


Figure S3: Powder $\mathrm{X}$-ray diffraction pattern of the solid mixture of green $\left(\mathrm{Na}_{\mathrm{x}} \mathrm{Np}\left(\mathrm{NpO}_{2}\right)_{6}(\mathrm{OH})_{1+\mathrm{x}} \mathrm{Cl}_{9}\left(\mathrm{H}_{2} \mathrm{O}\right)_{8-\mathrm{x}}(0<\mathrm{x} \leq 1)(2)\right.$ and 4$)$ and colorless products from one of rapid evaporation experiments.

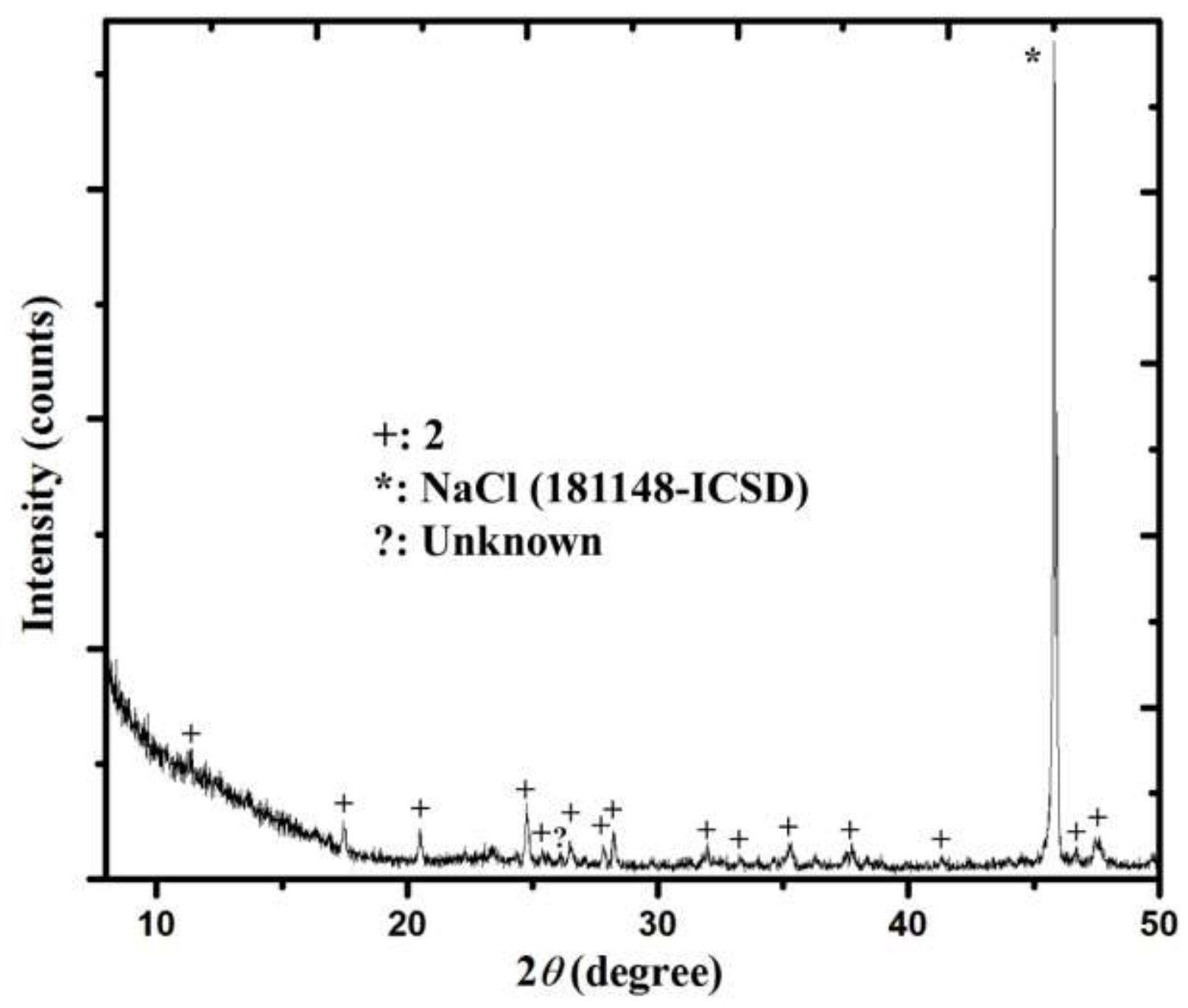


Figure S4: Raman spectra of a $\sim 1.0$ (black) and a $\sim 1.5 \mathrm{M}$ (red) $\mathrm{Np}(\mathrm{V})$ solutions.

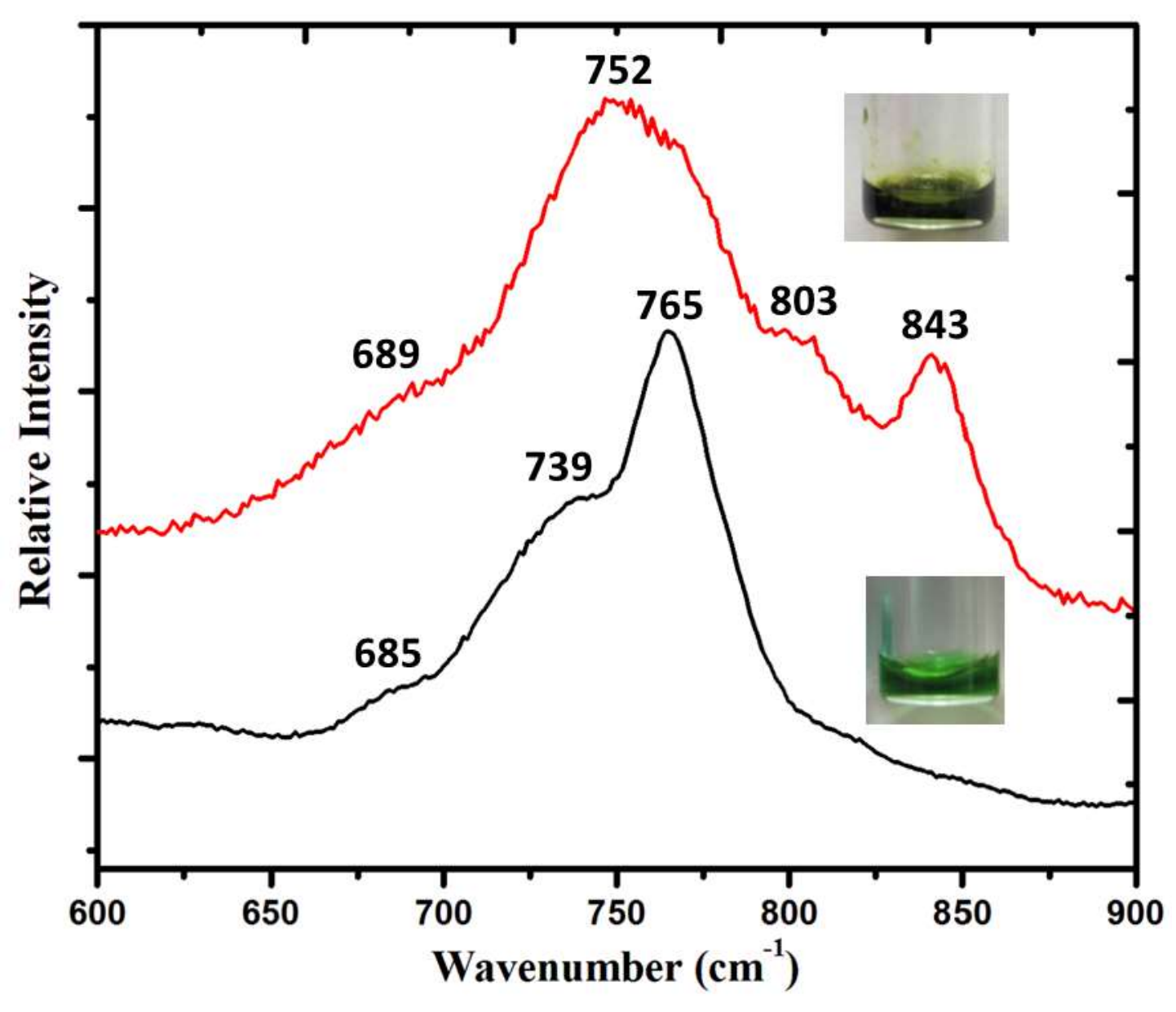


Figure S5: Raman spectra of $\left(\mathrm{NpO}_{2}\right)_{2}\left(\mathrm{C}_{4} \mathrm{O}_{4}\right)\left(\mathrm{H}_{2} \mathrm{O}\right)^{\mathrm{a}}$ (red) and $\left(\mathrm{NpO}_{2}\right)_{4} \mathrm{Cl}_{4}\left(\mathrm{H}_{2} \mathrm{O}\right)_{6} \cdot\left(\mathrm{H}_{2} \mathrm{O}\right)_{3}{ }^{\mathrm{b}}$ (black) with 2-D cationic CCI square sheets of neptunyl(V) pentagonal bipyramids. 654 and $666 \mathrm{~cm}^{-1}$, 799 and $816 \mathrm{~cm}^{-1}$ peaks are attributed to $v_{1}$ and $v_{3}$ modes of $\mathrm{NpO}_{2}^{+}$units, respectively. 637 and $726 \mathrm{~cm}^{-1}$ peaks are attributed to the vibrational modes of $\left[\mathrm{C}_{4} \mathrm{O}_{4}\right]^{2-}$ anions. ${ }^{1}$

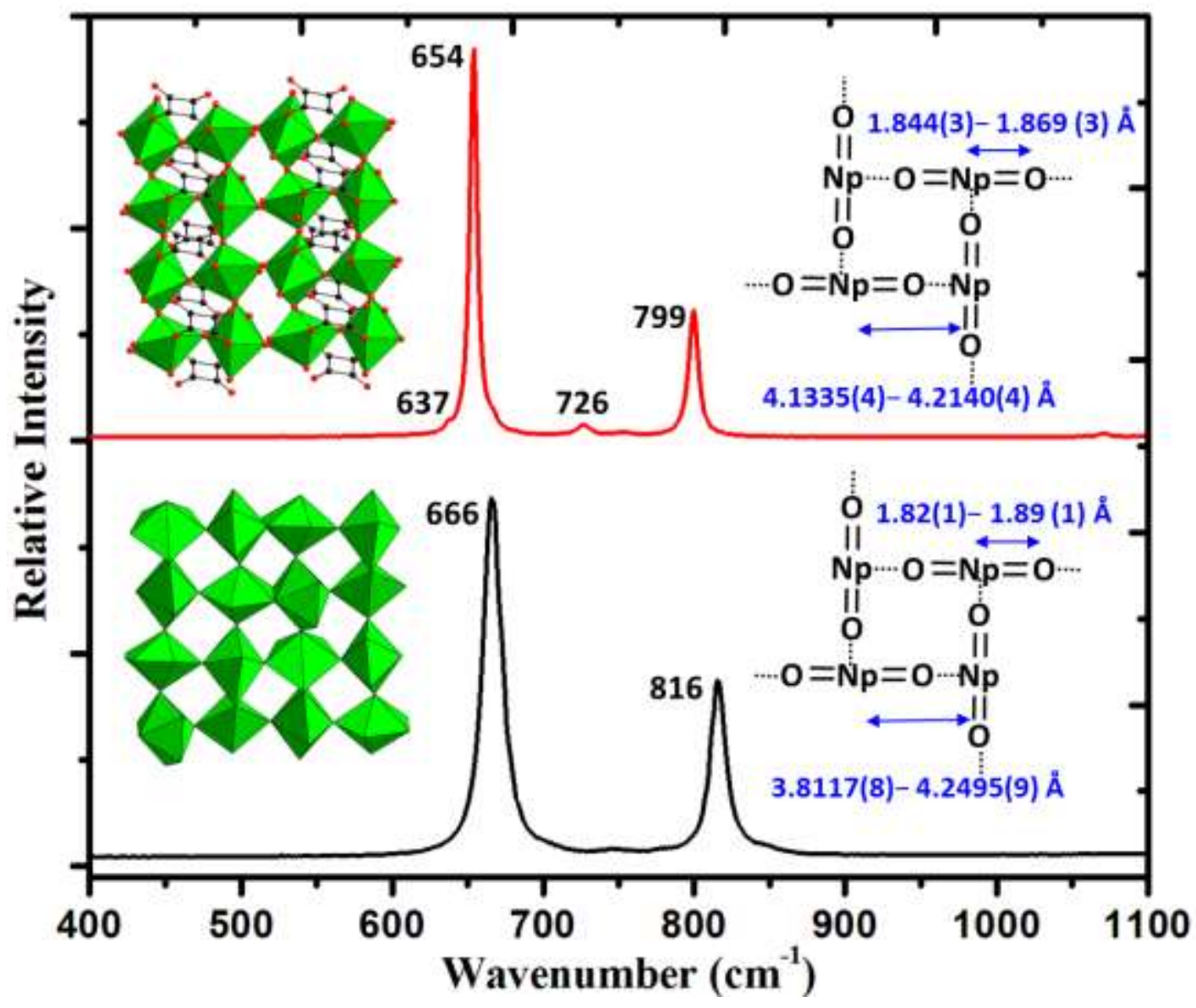

${ }^{\mathrm{a}}$ Green prisms of $\left(\mathrm{NpO}_{2}\right)_{2}\left(\mathrm{C}_{4} \mathrm{O}_{4}\right)\left(\mathrm{H}_{2} \mathrm{O}\right)$ were obtained from a hydrothermal treatment of a mixture of $0.080 \mathrm{~mL}$ of a $0.162 \mathrm{M}$ neptunium(V) stock solution (in $\sim 1 \mathrm{M} \mathrm{HCl}$ ), $2.4 \mathrm{mg}$ of $\mathrm{C}_{4} \mathrm{H}_{2} \mathrm{O}_{4}, 0.160 \mathrm{~mL}$ of a $1 \mathrm{M} \mathrm{KOH}$ solution, and $0.760 \mathrm{~mL} \mathrm{H}_{2} \mathrm{O}$ at $150{ }^{\circ} \mathrm{C}$ for 3 days. Crystallographic data: triclinic, $P-1, a=7.5696(7), b=8.1919(8) \AA, c=8.2955(8) \AA, \alpha=$ 90.218(1) ${ }^{\circ}, \beta=101.397(1)^{\circ}, \gamma=113.251(1), V=461.39(8) \AA^{3}, Z=2, \rho_{\text {calcd }}=4.506 \mathrm{~g} \mathrm{~cm}^{-3}, \mu=$ $224.03 \mathrm{~cm}^{-1}, R 1=0.0136, w R 2=0.0354$.

${ }^{\mathrm{b}}$ Green plate-like crystals of $\left(\mathrm{NpO}_{2}\right)_{4} \mathrm{Cl}_{4}\left(\mathrm{H}_{2} \mathrm{O}\right)_{6} \cdot\left(\mathrm{H}_{2} \mathrm{O}\right)_{3}$ were obtained from a evaporation experiment of a mixed $\mathrm{Np}(\mathrm{V})$ solution for several weeks in a similar fashion as $\mathbf{1}$. The reactants include $0.250 \mathrm{~mL}$ of a $0.120 \mathrm{M} \mathrm{Np}(\mathrm{V})$ stock solution (in $\sim 1 \mathrm{M} \mathrm{HCl}$ ), $5.8 \mathrm{mg}$ of $\mathrm{NaCl}, 0.250 \mathrm{~mL}$ of a concentrated $\mathrm{HCl}(12 \mathrm{M})$, and $0.250 \mathrm{~mL} \mathrm{H}_{2} \mathrm{O}$. The accuracy of crystallographic data and structural refinement results suffer severely from crystal twinning; nevertheless the connectivity 
between heavier $\mathrm{Np}$ atoms can be determined unambiguously from the X-ray diffraction experiments. The most reliable crystallographic data from numerous data collections: monoclinic, $C c, a=16.128(1), b=16.149(1) \AA, c=16.787(1) \AA, \beta=99.188(1)^{\circ}, V=4316.3(5)$ $\AA^{3}, Z=8, \rho_{\text {calcd }}=4.191 \mathrm{~g} \mathrm{~cm}^{-3}, \mu=196.59 \mathrm{~cm}^{-1}, R 1=0.0384, w R 2=0.1180$. 
Figure S6: Portion of the in situ Raman spectra of a evaporation process of a $1.5 \mathrm{M} \mathrm{Np}(\mathrm{V})$ solution using $10 \%$ laser power and $20 \%$ laser focus in less than an hour. The formation of green solid (5) is shown in the picture, which was obtained right after the experiment.

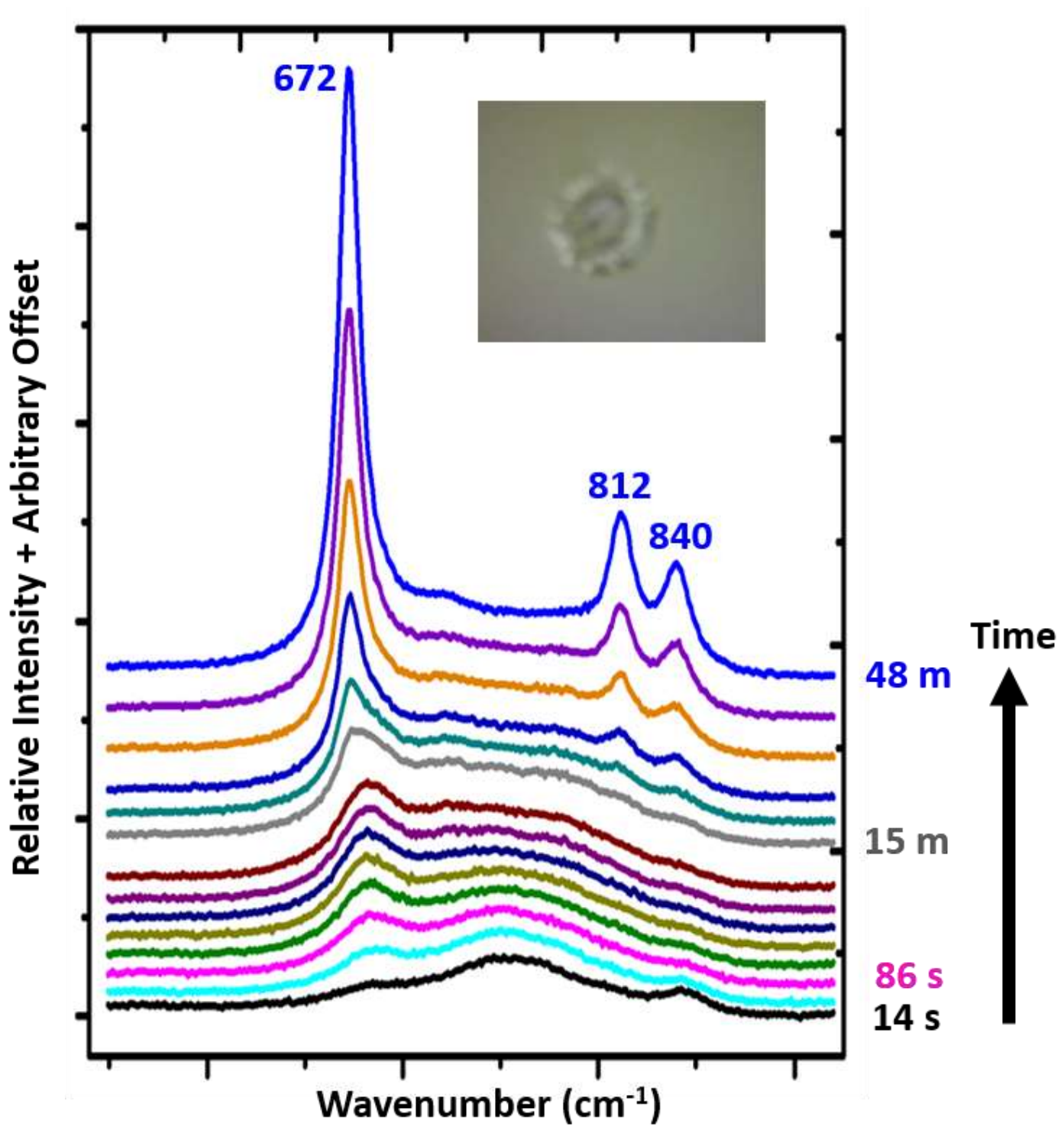


Figure S7: In situ Raman spectra of a evaporation process of a 1.5 M Np(V) solution using 10\% laser power and $0 \%$ laser focus in a few minutes. The formation of green $\mathrm{Na}_{\mathrm{x}} \mathrm{Np}^{\mathrm{IV}}\left(\mathrm{Np}^{\mathrm{V}} \mathrm{O}_{2}\right)_{6}(\mathrm{OH})_{1+\mathrm{x}} \mathrm{Cl}_{9}\left(\mathrm{H}_{2} \mathrm{O}\right)_{8-\mathrm{x}}(0<\mathrm{x} \leq 1)$ (2) solid is shown in the picture, which was obtained right after the experiment.

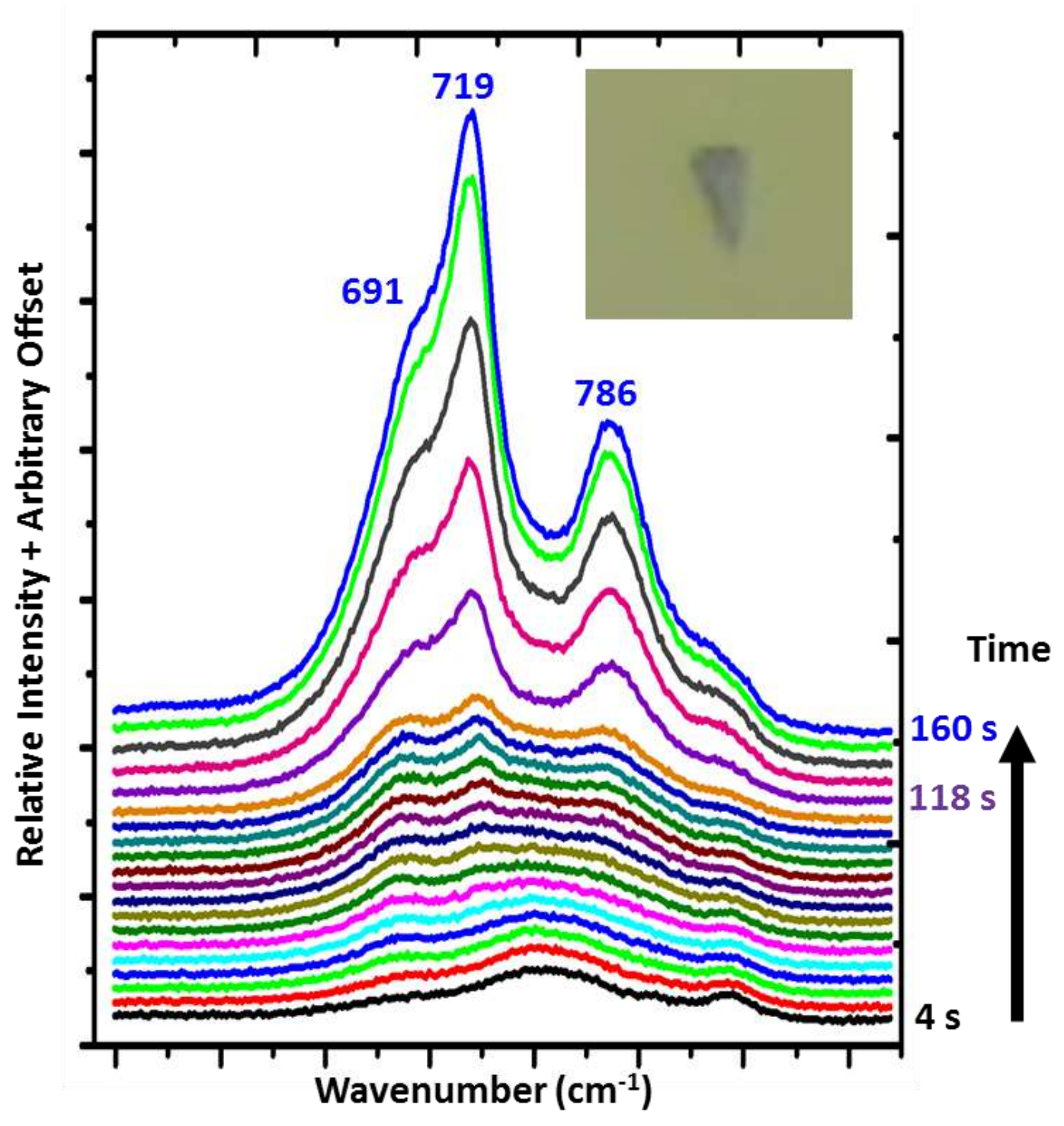


Figure S8: In situ Raman spectra of a evaporation process of a $1.0 \mathrm{M} \mathrm{Np}(\mathrm{V})$ solution using $50 \%$ laser power and $0 \%$ laser focus in approximately one minute. The green solid (6) formed in the middle of the evaporation is mostly disappeared at the end of the experiment as shown in the picture.

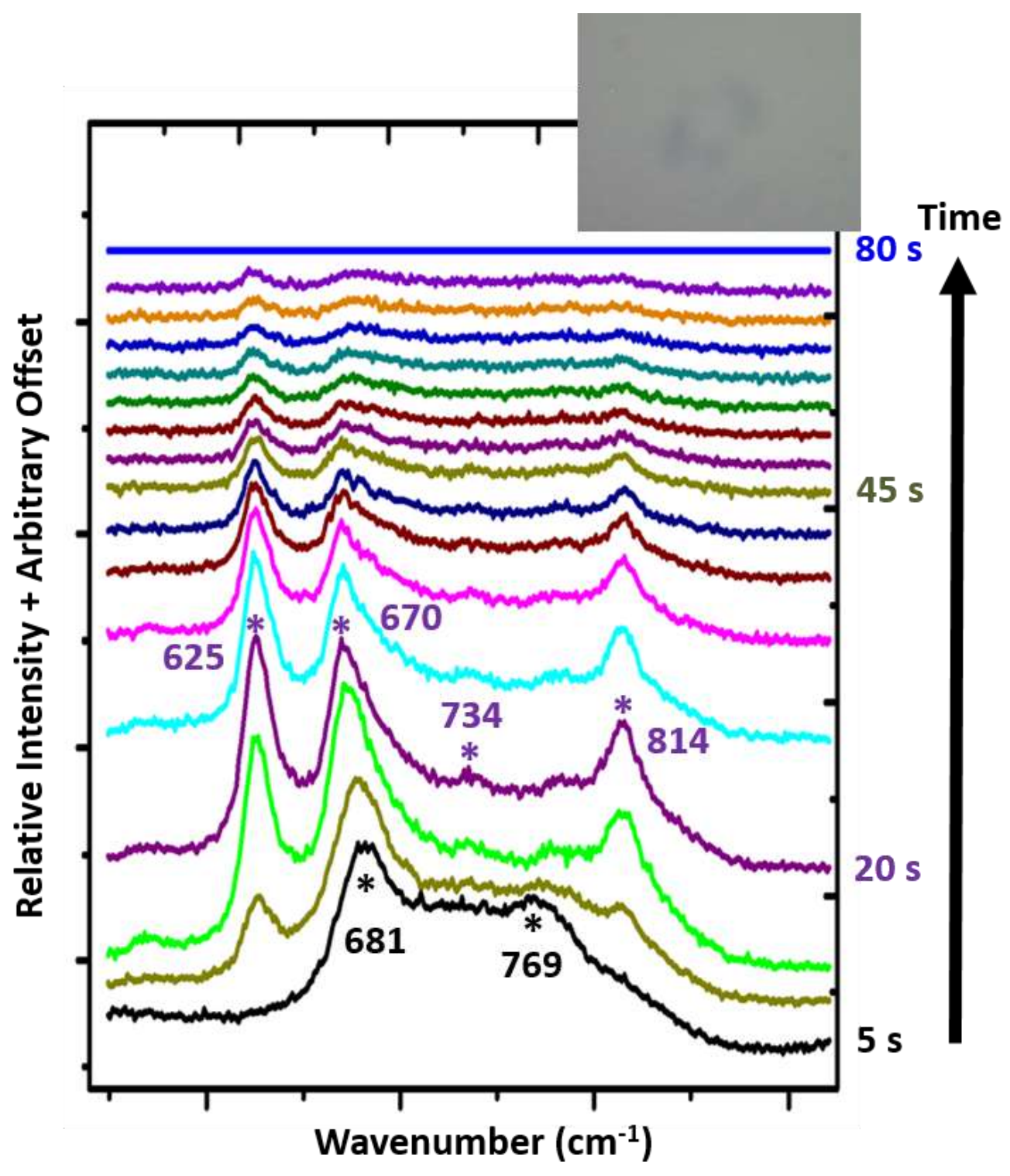




\section{References:}

(1) Nakashima, S.; Balkanski, M. Solid State Commun. 1976, 19, 1225-1228. 